\title{
Remember kerion celsi
}

\author{
Joao Brissos, ${ }^{1}$ Catarina Gouveia, ${ }^{2}$ Conceição Neves, ${ }^{2}$ Luís Varandas ${ }^{2}$
}

1 Department of Pediatrics, Hospital Dona Estefânia, Lisboa, Portugal

${ }^{2}$ Department of Pediatric Infectious Diseases, Hospital Dona Estefânia, Lisboa, Portugal

\section{Correspondence to}

Dr Joao Brissos,

brissosjoao@gmail.com
To cite: Brissos J,

Gouveia C, Neves $C$, et al. BMJ Case Rep Published online: [please include Day Month Year] doi:10.1136/ bcr-2013-200594

\section{DESCRIPTION}

A healthy 3-year-old boy presented to our emergency department with a 2-week history of inflammatory scalp lesions. Physical examination revealed diffuse erythematous lesions, with focal areas of alopecia and several pustular patches with extensive suppurative discharge (figures 1 and 2). Cervical lymphadenopathy and fever were also noted. Tinea capitis with secondary bacterial infection was diagnosed and fluconazol, intravenous flucloxacillin and clindamycin were given. Surgical drainage was performed due to multiple scalp abscesses. Trichophyton mentagrophytes was isolated from scalp brushings. A 5-month course of fluconazol was necessary for clinical cure. His mother had the same fungal infection (forearm skin lesion) and family reported guinea pig exposure for the past months.

Tinea capitis is the most frequent fungal infection in children. Zoophilic dermatophytes are responsible for severe inflammatory reactions probably due to their poor adaptation to the human host. Kerion celsi is an acute purulent inflammatory process of scalp, probably due to a T-cell-mediated hypersensitivity reaction to the dermatophyte. Griseofulvin is the first therapeutic choice since late 1950s, but is not available in certain European countries. Newer antifungal agents (terbinafine, itraconazole and fluconazole) seem to have similar efficacy rates. ${ }^{1}$ Treatment duration should be individualised according to severity and clinical response. ${ }^{2}$ Adjunctive treatment is controversial but data does not support antibiotics nor surgery for routine use. ${ }^{3}$ Tinea capitis and particularly kerion celsi, have a high potential for misdiagnosis.

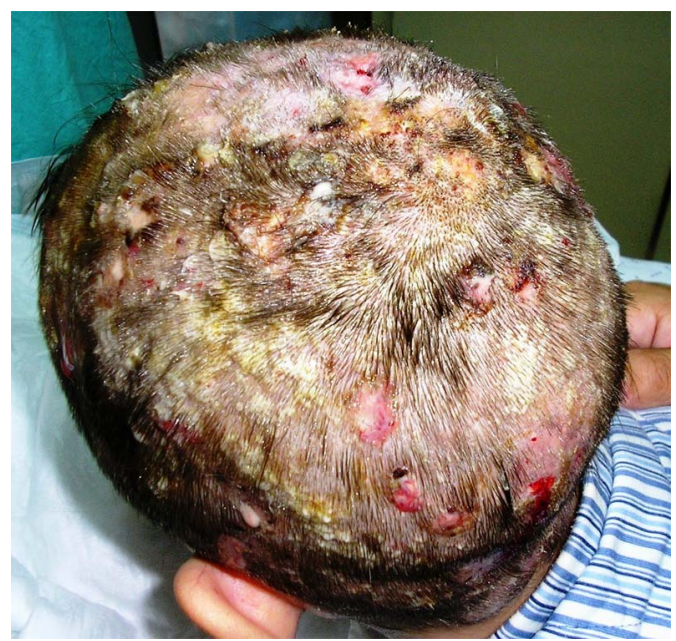

Figure 1 Pustular patches with extensive suppurative discharge.

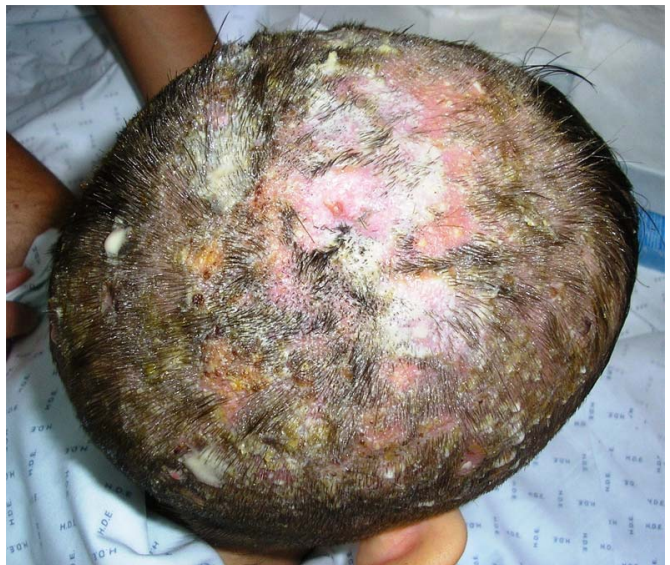

Figure 2 Diffuse inflammatory process with focal areas of alopecia.

Several cases are incorrectly diagnosed as bacterial infection. Delay in treatment led to more extensive, severe inflammation and consequently to scarring and alopecia in our case.

\section{Learning points}

- Tinea capitis is a superficial fungal infection of the scalp and is one of the most common dermatophytosis of childhood.

- The most inflammatory presentation is kerion, which is considered to be an exaggerated cell-mediated response to the fungus, often confused with a bacterial infection.

- Tinea capitis treatment in infants is still on debate, regarding newer oral antifungal agents. Duration of treatment should be individualised according to the response.

Contributors All the authors were responsible for the conception and design of the case report, critical revision and final approval of the version published.

\section{Competing interests None.}

Patient consent Obtained.

Provenance and peer review Not commissioned; externally peer reviewed.

\section{REFERENCES}

1 González U, Seaton T, Bergus G, et al. Systemic antifungal therapy for tinea capitis in children. Cochrane Database Syst Rev 2007;(4): CD004685

2 Kakourou T, Uksal U. Guidelines for the management of tinea capitis in children. Pediatr Dermatol 2010;27:226-8.

3 von Laer Tschudin L, Laffitte E, Baudraz-Rosselet F, et al. Tinea capitis: no incision nor excision. J Pediatr Surg 2007;42:E33-6. 
Copyright 2013 BMJ Publishing Group. All rights reserved. For permission to reuse any of this content visit http://group.bmj.com/group/rights-licensing/permissions.

BMJ Case Report Fellows may re-use this article for personal use and teaching without any further permission.

Become a Fellow of BMJ Case Reports today and you can:

- Submit as many cases as you like

- Enjoy fast sympathetic peer review and rapid publication of accepted articles

- Access all the published articles

- Re-use any of the published material for personal use and teaching without further permission

For information on Institutional Fellowships contact consortiasales@bmjgroup.com

Visit casereports.bmj.com for more articles like this and to become a Fellow 